\title{
Utilization of hydralazine hydrochloride in the Potentiometric Determination of Osmium(VIII): Analysis of Binary and Ternary Mixtures
}

\author{
A. S. Amin ${ }^{1}$ and H. M. Saleh ${ }^{2}$ \\ ${ }^{1}$ Chemistry Department, Faculty of Science, Benha University, Benha, Egypt \\ ${ }^{2}$ Pharmaceutical Chemistry Department, Faculty of Pharmacy, Zagazig University, Zagazig, Egypt.
}

\begin{abstract}
A simple, rapid and accurate potentiometric method is described for the determination of Os(VIII) in the concentration range $0.4-4.0 \mathrm{mg} / \mathrm{ml}$. The method is based on the addition of hydralazine hydrochloride to Os(VIII) to reduce it to Os (IV). The excess of hydralazine hydrochloride was oxidized by iodine dissolved in acetic acid. The liberated iodide was then potentiometrically titrated against mercury(II) using silver amalgam as the indicator electrode. The potential of this method for sime-microdetermination is important in practical applications where the above reaction should proceed quantitatively towards completion. The relative standard deviation for six replicate determination of osmium(VIII) in binary and ternary mixtures without the need for extraction or heating.
\end{abstract}

Key words: Potentiometric titrations, osmium determination, hydralazine hydrochloride.

\section{Introduction}

Hydralazine hydrochloride is (1-hyrazinophthalazine) mono-hyrochloride [30420-1]. It has been widely used for treatment of hypertension. It is also act as reducing agent, and form complexes with many metal ions ${ }^{(1)}$. Khalifa et al ${ }^{(2)}$, suggested a potentiometric method for the determination of osmium(VIII) using iodide. Jankauskas and Norkus ${ }^{(3)}$ used osmium tetraoxide for the potentiometric determination of $\mathrm{Cr}$ (III) with hexacyanoferrate(III) in alkaline medium. Zaky and Issa described potentiometric methods for the determination of osmium (VIII) using hydrazine sulphate ${ }^{(4)}$ or sodium arsenite ${ }^{(5)}$. Santrucek et al ${ }^{(6)}$, used an oxidimetric method for the determination of Os(IV). Dikshitulu et al (7) used iron (II) in a titrimetric method for the determination of osmium(VIII) and iridium(IV). Roy et al (8) described a selective spectro-photometric method for the determination of palladium and osmium in strongly acidic media using 1-(1-naphthyl)-4,4,6-trimethyl$1 \mathrm{H}, 4 \mathrm{H}$-pyrimidine-2-thiol. Puzanowska et al ${ }^{(9)}$ suggested a spectrophotometric method for the determination of osmium(VIII) with promazine hydrochloride in acidic media. Martynov ${ }^{(10)}$ determined osmium(VIII) spectrophotometrically with sodium thiosulfate or tetrahydroborate in alkaline media. Popper et al ${ }^{(11)}$ determined osmium(VIII) photometrically in alkaline solution with 2-ethylthioisonicotinamide. 
The present study describes a new potentiometric method for the simemicrodetermination of osmium by reduction with excess of hydralazine hydrochloride and then oxidation the unreacted hydralazine hydrochloride using iodine, the liberated iodide was then titrated potentiometrically with $\mathrm{Hg}$ (II). The proposed method has the advantage of being simple, rapid, accurate, precise, highly reproducible with reasonable selectivity, over conventional method ${ }^{(3,12,13)}$, wide range of determination over other methods ${ }^{(1-11)}$, in addition to simplicity of reagents and apparatus. Further, osmium in synthetic binary and ternary mixtures of common metal ions that usually accompany osmium in nature and manufactured samples is determined by this method.

\section{Experimental}

Solutions

All solutions were prepared from analaR grade chemicals and deionized water, and were standardized by the recommended method ${ }^{(14)} .0 .0385 \mathrm{M}$ mercuric nitrate (Aldrich product) were prepared by dissolving the appropriate weight in water and standardized according to previously method ${ }^{(14)}$.

Osmium solution; Osmium tetroxide stock solution was prepared by dissolving $1.00 \mathrm{~g}$ of osmium tetroxide (Aldrich) from a sealed ampoule in about $100 \mathrm{ml}$ of 0.2 $M$ sodium hydroxide solution in a glass-stoppered $1.00 \mathrm{~L}$. Calibrated flask (taking into account the significant vapour pressure of $\mathrm{OsO}_{4}$ at room temperature and slow reduction of Os(VIII) to Os(IV) when osmium tetroxide is dissolved in $\mathrm{NaOH}$ solution. The solution was then diluted with water and standardized iodometrically (12). Working solution of $0.0105 \mathrm{M}$ was prepared by appropriates dilution of the above stock solution and standardized iodometrically ${ }^{(12)}$.

Iodine solution; $2.0 \%$, Previously sublimed solid iodine was dissolved in $75 \%$

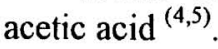

Hydralazine hydrochloride solution; 0.0205M, Dissolve the solid in water and standardized iodometrically.

Vanadium(IV) solution; $0.0405 \mathrm{M}$, The appropriate weight of ammonium metavanadate $\left(\mathrm{NH}_{4} \mathrm{VO}_{3}\right)$ dissolved in water. The resulting solution was reduced with $\mathrm{Na}_{2} \mathrm{SO}_{3}{ }^{(15)}$, boiled for $20 \mathrm{~min}$ to ensure complete transformation of $\mathrm{V}$ (V) to $\mathrm{V}$ (IV) and to expel the excess of $\mathrm{SO}_{2}$, and diluted with water to the required volume. The solution was standardized potentiometrically with EDTA as complexone using platinum electrode as indicator electrode.

Urotropine solution; $8 \%$. Solution was prepared in distilled water. This solution was used for $\mathrm{pH}$ adjustment.

Other solutions; 0.0462 EDTA, $0.0385 \mathrm{M} \mathrm{Hg}\left(\mathrm{NO}_{3}\right)_{2}, 0.0478 \mathrm{M} \mathrm{KI}, 0.0225 \mathrm{M}$ $\mathrm{AgNO}_{3}, 0.0227 \mathrm{M} \mathrm{NiSO}, 0.0349 \mathrm{M} \mathrm{CoSO}, 0.0302 \mathrm{M} \mathrm{Cr}_{2}\left(\mathrm{SO}_{4}\right)_{3}, 0.0377 \mathrm{M}$ $\mathrm{Al}_{2}\left(\mathrm{SO}_{4}\right)_{3}, \quad 0.0501 \mathrm{M} \mathrm{KBrO}, 0.0313 \mathrm{M} \mathrm{CuSO}_{4}, 0.0259 \mathrm{M} \mathrm{PtCl}_{2}$ and $0.0252 \mathrm{M}$ $\mathrm{Fe}_{2}\left(\mathrm{SO}_{4}\right)_{3}$, solutions were prepared and standardized them as previously described $^{(16-18)}$. 


\section{Apparatus}

The titration assembly consisted of a $100-\mathrm{ml}$ beaker fitted with a silver amalgam indicator electrode and a saturated calomel electrode, a 5.0- $\mathrm{ml}(0.01 \mathrm{scale}$ microburette, a magnetic stirrer and a potentiometer (an Orion Research Model 601 A/Digital ionalyzer).

\section{1-Determination of osmium(VIII)}

Aliquot of $2.0 \mathrm{ml}$ of $0.0105 \mathrm{M} \mathrm{Os(VIII)} \mathrm{solution} \mathrm{was} \mathrm{transferred} \mathrm{from} \mathrm{the}$ microburette into a $100-\mathrm{ml}$ Pyrex cell and $1.0 \mathrm{ml}$ of $2.0 \% \mathrm{HCl}$ was added and followed by $2.0-8.0 \mathrm{ml}$ of $0.0205 \mathrm{M}$ hydralazine hydrochloride $(\mathrm{pH} 3.2)$, the solution was left for about 2.0 min to ensure complete reduction of Os(VIII) to Os(IV), which is shown by transformation of the yellow to a brownish red colour, an excess of iodine solution was added and dissolved in acetic acid $(4,5)$ of oxidise unreacted hydralazine hydrochloride and the liberated iodide was titrated with $0.0385 \mathrm{M} \mathrm{Hg}$ (II) [Fig. 1] as optimum titrant for highly change in potential at the end point. The amount of hydralazine hydrochloride equivalent to osmium(VIII) as calculated.

\section{2-Analysis of synthetic mixtures}

Synthetic mixture were prepared by mixing different concentration of pure standard materials prepared above with different volume of $0.0105 \mathrm{M}$ osmium solution as recorded in Table ( 3 and 4 ) and completed to the mark with water in a 10 $\mathrm{ml}$ calibrated flask. The mixtures were analyzed using following procedures.

\section{Results and Discussion}

The proposed method depends essentially on adding to osmium(VIII) a known excess amount of hydralazine $\mathrm{HCl}$, then oxidizing unreacted hydralazine $\mathrm{HCl}$ with iodine dissolved in acetic acid and titrated the liberated iodide with $\mathrm{Hg}$ (II) using silver amalgam as the indicator electrode

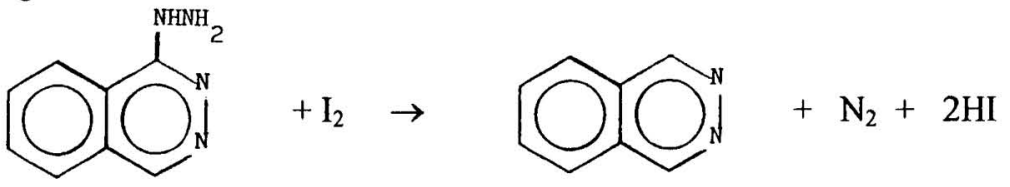

Careful investigations were carried out to demonstrate the most favourable conditions to achieve maximum and constant $\mathrm{mV}$ reading in the quantitative determination of osmium [Fig. 1]. The effect of the following variables on the reaction was examined. 


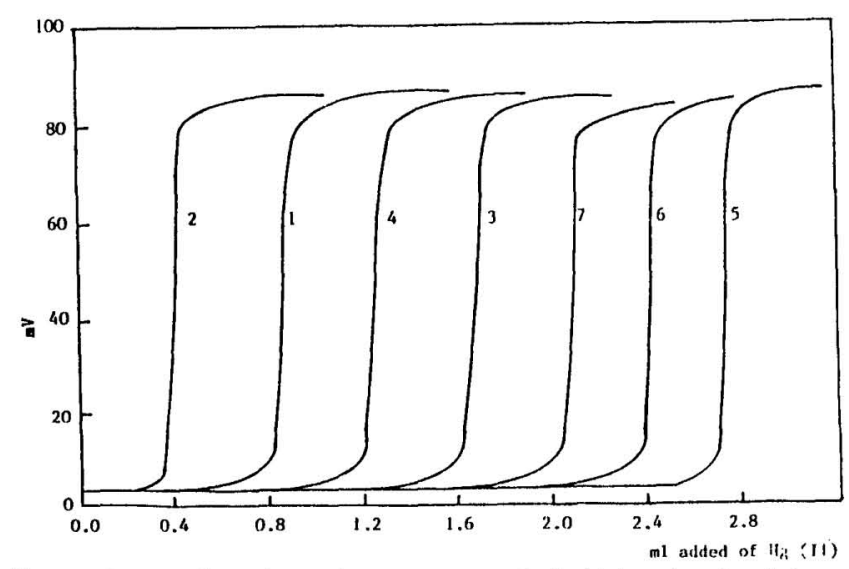

Fig. (1): Potentiometric titration curves of Iolide oltatined by oxidired unreacted hydralazine IIC1 resulting from the reaction of:

1. $0.2 \mathrm{ml} 0.0105 \mathrm{M}$ Os (VIII) $+2 \mathrm{ml} 0.0205 \mathrm{M}$ hydralazine IICl.

2. $0.6 \mathrm{ml} 0.0105 \mathrm{M} \mathrm{Os}$ (VIII) + $2 \mathrm{ml} 0.0205 \mathrm{M}$ hydralazine $\mathrm{IICl}$.

3. $0.4 \mathrm{ml} 0.0105 \mathrm{M} \mathrm{Os}$ (VIII) + $4 \mathrm{ml} 0.0205 \mathrm{M}$ hydralazine $\mathrm{HCl}$.

4. $0.8 \mathrm{ml} 0.0105 \mathrm{M} \mathrm{Os}$ (VIII) + $4 \mathrm{ml} 0.0205 \mathrm{M}$ hydralazine HC1.

5. $1.4 \mathrm{~m} 10.0105 \mathrm{M}$ Os (VIII) $+8 \mathrm{ml} 0.02 \Omega 5 \mathrm{M}$ hydralazine $\mathrm{HC1}$.

6. $1.7 \mathrm{ml} 0.0105 \mathrm{M} \mathrm{Os}$ (VIII) $+8 \mathrm{ml} 0.0205 \mathrm{M}$ hydralazine $\mathrm{HCl}$.

7. $2.0 \mathrm{~mL} 0.0105 \mathrm{M} \mathrm{Os}$ (VIII) + $8 \mathrm{ml} 0.0205 \mathrm{M}$ hydralazine HCl.

\section{Effect of reagent concentration}

The results obtained indicated that at least $2.0 \mathrm{ml} 0.0205 \mathrm{M}$ hydralazine $\mathrm{HCl}$ should be present for complete reduction process in low concentration level of osmium whereas $6.0 \mathrm{ml}$ of the reagent should be present to achieve maximum reduction in high concentration level. However, 2.0-8.0 $\mathrm{ml} 0.0205 \mathrm{M}$ hydralazine $\mathrm{HCl}$ was used in the present study to insure quantitative reaction at the upper limit of determination.

\section{Effect of acidity}

The effect of acidity was investigated using nitric, phosphoric, sulphoric, acetic and hydrochloric acid. Complete reduction process with highly accuracy and precision was obtained on using hydrochloric acid rather than acids under examination due to the formation of $\mathrm{OsCl}_{6}{ }^{2-}$ with the $\mathrm{Os}(\mathrm{IV})$ results from the reduction process. The effect of varying amount of $\mathrm{HCl}$ was investigated and found to be $1.0 \mathrm{ml}$ of $2.0 \% \mathrm{HCl}$ which adjusted the $\mathrm{pH}$ of solution mixture to 3.2 , the $\mathrm{Cl}^{-}$ ion present in the solution introduce in the formation of $\mathrm{OsCl}_{6}{ }_{6}^{2-}$. Excess amount of $\mathrm{HCl}$ causing interference in the determination of iodide with $\mathrm{Hg}$ (II) and so decrease the accuracy of the determination.

\section{Effect of time and temperature}

The results obtained indicated that complete reduction of Os(VIII) to Os(IV) was occurred instantaneously at room temperature and the brownish red colour of Os(IV) remains on raising the temperature upto $100^{\circ} \mathrm{C}$. In aqueous solution with a $\mathrm{pH}$ greater than 7.0, hydralazine decomposes, forming phthalazine; the rate of 
In order to establish whether the proposed method exhibits any fixed or proportional bias, a simple linear regression ${ }^{(20)}$ for Os(VIII) concentration was calculated (dependent variable). A student's $t-$ and $F$ - test ${ }^{(20)}$ (at $95 \%$ confidence level) was applied to the slope and the intercept of the regression line [Table 2]. Statistical analysis of the data shows that the calculated slope and intercept do not differ significantly from the ideal value of unity and zero, respectively. Hence it can be concluded that there are no systematic difference between the determined and true concentrations over the examined range. The measured standard deviation (S.D.), relative standard deviation (R.S.D.), the standard analytical error and confidence limits [Table 1] can be considered satisfactory at least for the level of concentrations examined.

Table (2): Linear regression analysis for Os(VIII).

\begin{tabular}{|c|c|c|c|}
\hline Parameter & Os(VIII) & Parameter & Os(VIII) \\
\hline $\begin{array}{l}\text { Optimum concentration } \\
\text { range }(\mathrm{mg} / \mathrm{ml})\end{array}$ & $0.4-4.0$ & $\begin{array}{l}\text { Calculated t-value } \\
(2.57)^{*}\end{array}$ & 1.93 \\
\hline $\begin{array}{l}\text { Regression coefficient } \\
\text { or slope of regression }\end{array}$ & 0.9978 & $\begin{array}{l}\text { Calculated F- } \\
\text { value }(5.05)^{*}\end{array}$ & 2.07 \\
\hline $\begin{array}{l}\text { Shift or intercept of the } \\
\text { regression line }\end{array}$ & 0.019 & Range of error $\%$ & $100 \pm 1.15$ \\
\hline
\end{tabular}

The present method for binary and ternary mixtures is highly reliable, because they involve potentiometric endpoint determination [Fig. 2], which is known to be highly accurate [Table 3 and 4].

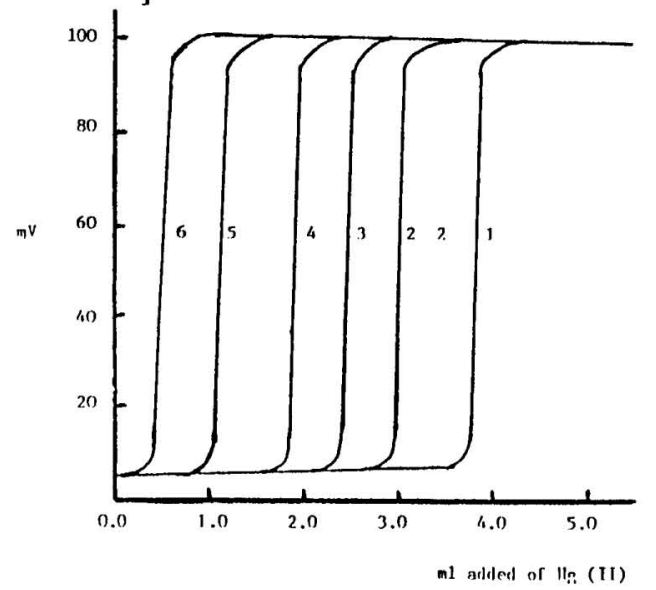

Fig. (2): Potentiometric titration curves for binary and ternary mixture

1. $0.4 \mathrm{ml} \mathrm{Os}$ (VIII) + $2.0 \mathrm{ml} \mathrm{V}$ (VI) $+8 \mathrm{~m} 1$ hydralazine $\mathrm{HCl}$.

2. $0.6 \mathrm{ml} \mathrm{Os} \mathrm{(VIII)}+1.0 \mathrm{ml} \mathrm{Ag}$ (I) $+8 \mathrm{ml}$ hydralazine HCl.

3. $0.4 \mathrm{ml} \mathrm{Os}$ (VIII) + $1.0 \mathrm{ml} \mathrm{Pt}$ (II) $+8 \mathrm{ml}$ hydralazine HCl.

4. $0.8 \mathrm{ml} \mathrm{Os} \mathrm{(VIII)}+2.5 \mathrm{ml} \mathrm{Ag}$ (I) $+1 \mathrm{ml} \mathrm{V}$ (VI) $+8 \mathrm{ml}$ hydralazine $\mathrm{HCl}$.

5. $1.0 \mathrm{ml} \mathrm{0s}$ (VIII) $+3.5 \mathrm{ml} \mathrm{Ag}(\mathrm{I})+2.0 \mathrm{ml} \mathrm{Ni}$ (II) $+8.0 \mathrm{ml}$ hydralazine $\mathrm{HCl}$.

6. $1.0 \mathrm{ml} \mathrm{Os}$ (VIII) $+2.0 \mathrm{ml} \mathrm{Pt}$ (II) $+2.0 \mathrm{ml}$ Co (II) $+8.0 \mathrm{~m} 1$ hydralazine $\mathrm{HCl}$. 
decompositions depends on $\mathrm{pH}$, temperature and the kind and the concentration of anion present. At higher temperature and in acidic medium, hydralazine decomposed mainly to hydrazine ${ }^{(19)}$. The quantitativeness of the redox reactions involving Os(VIII) as oxidant and hydralazine as the reductant may be predicted by considering the standard reduction potentials of the half-reactions involved.

$$
\begin{gathered}
\mathrm{C}_{8} \mathrm{H}_{8} \mathrm{~N}_{4}+2 \mathrm{H}^{+} \rightarrow \mathrm{N}_{2} \mathrm{H}_{4}+\mathrm{C}_{8} \mathrm{H}_{6} \mathrm{~N}_{2} \\
\mathrm{~N}_{2} \mathrm{H}_{4} \rightarrow \mathrm{N}_{2}+4 \mathrm{H}^{+}+4 \mathrm{e} \mathrm{E}^{\circ}=+0.22 \mathrm{~V} \\
\mathrm{OsO}_{4}+8 \mathrm{H}^{+}+6 \mathrm{Cl}^{-}+2 \mathrm{e} \rightarrow \mathrm{OsCl}_{6}^{2-}+4 \mathrm{H}_{2} \mathrm{OE}^{\circ}=+1.00 \mathrm{~V} \\
\mathrm{OsO}_{4}+\mathrm{N}_{2} \mathrm{H}_{4}+4 \mathrm{H}^{+} \rightarrow \mathrm{OsCl}_{6}^{2-}+\mathrm{N}_{2}+4 \mathrm{H}_{2} \mathrm{O} \mathrm{E}^{\circ}=+1.22 \mathrm{~V}
\end{gathered}
$$

By using the relation of $E^{\circ}=(0.0592 / n) \log \mathrm{K}$, where $\mathrm{E}^{\circ}$ is the standard potential, $n$ is the number of electrons evolved to reduce one mole of Os(VIII) to $\mathrm{Os}(\mathrm{VI})$, and $\mathrm{K}$ is the equilibrium formation constant of the reaction. The $\log \mathrm{K}$ value was calculated to be 82.57 . Such value indicates that the above reaction should proceed quantitatively towards completion. The degree of completion of the reaction $(\alpha)$ is calculated according to $\alpha=\log \mathrm{K} / \mathrm{n}_{1}+\mathrm{n}_{2}=82.57 / 6=13.76$.

\section{Analytical data}

The data obtained from potentiometric titration show that accurate results are obtained with a good recovery over the concentration range $0.4-4.0 \mathrm{mg} / \mathrm{ml}$, above which low accuracy with more error than $2.0 \%$ are obtained as summarized in Table (1). The equivalence points were accurately determined with potential breaks ranging from 202 to $218 \mathrm{mV} / 0.1 \mathrm{ml}$ of $\mathrm{Hg}(\mathrm{II})$, sharp enough for the accurate determination of the endpoint.

Table (1): Evaluation of accuracy and precision of the proposed potentiometric titration method.

\begin{tabular}{ccccccc}
\hline $\begin{array}{c}\text { Taken } \\
\mathbf{m g} / \mathbf{m l}\end{array}$ & $\begin{array}{c}\text { Found }^{\mathbf{n}} \\
\mathbf{m g} / \mathbf{m l}\end{array}$ & $\begin{array}{c}\text { Recover } \\
\mathbf{y} \%\end{array}$ & $\begin{array}{c}\mathbf{\text { SSD }} \\
\mathbf{\%}\end{array}$ & $\begin{array}{c}\text { RSD } \\
\%\end{array}$ & $\begin{array}{c}\text { Standard } \\
\text { error }\end{array}$ & $\begin{array}{c}\text { Confidence } \\
\text { limits }\end{array}$ \\
\hline 0.399 & 0.397 & 99.50 & 0.07 & 0.37 & 0.029 & $0.397 \pm 0.080$ \\
0.799 & 0.805 & 100.75 & 0.08 & 0.43 & 0.033 & $0.805 \pm 0.091$ \\
1.198 & 1.210 & 101.00 & 0.11 & 0.89 & 0.045 & $1.210 \pm 0.125$ \\
1.698 & 1.585 & 99.19 & 0.07 & 0.39 & 0.029 & $1.585 \pm 0.080$ \\
1.997 & 2.020 & 101.15 & 0.09 & 0.51 & 0.037 & $2.020 \pm 0.103$ \\
2.397 & 2.370 & 98.87 & 0.09 & 0.57 & 0.037 & $2.370 \pm 0.103$ \\
2.796 & 2.780 & 99.43 & 0.10 & 0.78 & 0.041 & $2.780 \pm 0.114$ \\
3.195 & 3.210 & 100.47 & 0.11 & 0.84 & 0.045 & $3.210 \pm 0.125$ \\
3.595 & 3.580 & 99.58 & 0.06 & 0.46 & 0.024 & $3.580 \pm 0.069$ \\
3.994 & 4.000 & 100.15 & 0.14 & 1.22 & 0.057 & $4.000 \pm 0.160$ \\
4.393 & 4.300 & 97.88 & 0.20 & 1.88 & 0.083 & $4.300 \pm 0.230$ \\
\hline
\end{tabular}

${ }^{a}$ Average of six determinations 
Table (3): Representative results for analysis of binary complexes.

\begin{tabular}{lllll}
\hline $\begin{array}{l}\text { Os(VIII) taken } \\
\mathbf{m g / m l}\end{array}$ & $\begin{array}{l}\text { Found" } \\
\mathbf{m g} / \mathbf{m l}\end{array}$ & Metal & $\begin{array}{l}\text { Metal taken } \\
\mathbf{m g} / \mathbf{m l}\end{array}$ & $\begin{array}{l}\text { Metal } \\
\mathbf{m g} / \mathbf{m l}\end{array}$ \\
\hline 0.80 & 0.81 & $\mathrm{Pt}$ & 5.05 & 5.00 \\
1.60 & 1.59 & & 2.53 & 2.55 \\
0.60 & 0.59 & $\mathrm{Ag}$ & 4.85 & 4.90 \\
1.20 & 1.21 & & 2.43 & 2.80 \\
0.60 & 0.60 & $\mathrm{Al}$ & 3.05 & 3.10 \\
1.60 & 1.59 & & 1.02 & 1.10 \\
1.00 & 0.99 & $\mathrm{Fe}$ & 1.41 & 1.45 \\
2.40 & 2.44 & & 4.22 & 4.25 \\
0.80 & 0.81 & $\mathrm{Cu}$ & 1.99 & 2.00 \\
2.00 & 2.00 & & 3.98 & 3.90 \\
0.60 & 0.61 & $\mathrm{Ni}$ & 4.00 & 3.95 \\
2.60 & 2.57 & & 6.66 & 6.60 \\
0.60 & 0.60 & $\mathrm{Co}$ & 3.09 & 3.10 \\
1.80 & 1.81 & & 8.23 & 8.20 \\
0.80 & 0.79 & $\mathrm{Cr}$ & 6.28 & 6.30 \\
2.20 & 2.22 & & 3.14 & 3.20 \\
0.80 & 0.79 & $\mathrm{~V}$ & 8.25 & 8.20 \\
2.40 & 2.43 & & 4.13 & 4.20 \\
\hline
\end{tabular}

average of five determinations.

Table (4): Representative results for analysis of ternary mixtures

\begin{tabular}{|c|c|c|c|c|c|c|c|}
\hline \multicolumn{2}{|c|}{ Os(VIII) $\mathrm{mg} / \mathrm{ml}$} & \multirow[b]{2}{*}{ Metal } & \multirow{2}{*}{$\begin{array}{l}\text { Metal } \\
\text { taken } \\
\mathrm{mg} / \mathrm{ml}\end{array}$} & \multirow{2}{*}{$\begin{array}{l}\text { Metal } \\
\text { found } \\
\mathrm{mg} / \mathrm{ml}\end{array}$} & \multirow[b]{2}{*}{ Metal } & \multirow{2}{*}{$\begin{array}{l}\text { Metal } \\
\text { taken } \\
\mathrm{mg} / \mathrm{ml}\end{array}$} & \multirow{2}{*}{$\begin{array}{l}\text { Metal } \\
\text { found } \\
\mathrm{mg} / \mathrm{ml}\end{array}$} \\
\hline Taken & Found $^{\mathrm{a}}$ & & & & & & \\
\hline 1.00 & 1.00 & Pt & 5.05 & 5.10 & $\mathrm{Co}$ & 2.06 & 2.05 \\
\hline 2.00 & 1.99 & & 10.11 & 10.10 & & 4.11 & 4.05 \\
\hline 3.00 & 3.02 & & 15.56 & 15.50 & & 8.23 & 8.25 \\
\hline 0.60 & 0.59 & & 2.53 & 2.55 & $\mathrm{Ni}$ & 4.00 & 4.00 \\
\hline 1.80 & 1.83 & & 7.58 & 7.55 & & 6.66 & 6.65 \\
\hline 2.40 & 2.44 & & 12.63 & 12.70 & & 8.00 & 8.05 \\
\hline 0.80 & 0.81 & $\Lambda \mathrm{g}$ & 2.43 & 2.45 & Co & 3.09 & 3.10 \\
\hline 1.60 & 1.58 & & 4.85 & 4.80 & & 5.14 & 5.20 \\
\hline 2.40 & 2.38 & & 7.28 & 7.25 & & 7.20 & 7.25 \\
\hline 0.60 & 0.59 & & 3.64 & 3.65 & $\mathrm{Ni}$ & 2.66 & 2.65 \\
\hline 1.00 & 1.01 & & 6.07 & 6.05 & & 4.00 & 4.00 \\
\hline 2.00 & 2.01 & & 8.50 & 8.55 & & 5.33 & 5.30 \\
\hline 0.60 & 0.61 & $\mathrm{Ag}$ & 1.21 & 1.25 & $\mathrm{Cr}$ & 1.57 & 1.55 \\
\hline 1.60 & 1.57 & & 3.64 & 3.60 & & 3.14 & 3.10 \\
\hline 3.00 & 2.97 & & 6.07 & 6.00 & V & 6.28 & 6.30 \\
\hline 0.8 & 0.81 & & 2.43 & 2.40 & & 2.06 & 2.05 \\
\hline 1.60 & 1.59 & & 6.07 & 6.00 & & 4.13 & 4.10 \\
\hline 2.60 & 2.58 & & 9.71 & 9.65 & & 6.19 & 6.15 \\
\hline
\end{tabular}

Average of five determinations.

\section{Conclusion}

The proposed method compares will with the other ${ }^{(1-10)}$, in regard to simplicity, rapidity, highly reproducibility with reasonable selectivity, highly accurate and precise, in addition to simplicity of reagents and apparatus. With the proposed method it is possible to determine osmium at wide range from $0.4-4.0 \mathrm{mg} / \mathrm{ml}$. The method was applied to a variety of synthetic binary and ternary mixtures to evaluate its effectiveness [Table 3 and 4]. Mixtures of common metal ions that usually accompany osmium in natural and manufactured samples were prepared and analyzed. 


\section{References}

1. Kalifa H.,Abdel Ghani N.T., Rizk M.S.,(1979), Analyst 104: 576.

2. Jankauskas J., Norkus P., (1972) Zh. Anal. Khim. 27: 1629.

3. ZakyM., Issa Y.M., (1984), Analyst 109: 1107.

4. Zaky M., Killa H.M., Issa Y. M., (1991), Microchem. J. 44: 54.

5. Santrucek J., Nemic I., Zyka J., (1966), Collect. Czech. Chem. Commun. 31 : 2679.

6. Dikshitulu L.S.A., Raju K.V., Dindi S.N., (1981), J. Indian Chem. Soc. $58: 415$.

7. Roy B., Singh R.P., Singh A.K., (1981), J. Indian Sci. Sect. B, 63: 13.

8. Puzanowska-Tarasiewicz H., Kojlo A., Zawadzka L., (1981), Microchem. J. 26: 360.

9. Martynov V.I., (1981), Zh. Anal. Khim. (1981) 58: 415.

10. Popper E., Grecu I., Pitea I., Chiorean L., Gocan I., (1964), Rev. Roum.Chim. 9: 383.

11. Fallab S., (1962), Helv. Chim. Acta 45: 1957.

12. Gowda A.T., Gowda H.S., Gowda N.M.N, (1984), Analyst 109: 651.

13. Bardin M.B., Goncharenko V.P., (1970), Zh. Neorg. Khim. 15: 419.

14. Kolthoff I.M., Philip J.E., (1966), "Treaties on Analytical Chemistry" Vol. 4. Part II, P. 52-63.

15. Khalifa H., Ghonaim A. Kh., Ismail I. A., (1974), Z. Anal. Chem. 272: 367.

16. Welcher F.J., (1952), “The Analytical Uses of Ethylenediamine-tetraacetic acid" Van Nostrand, Princeton, NJ.

17. Khalifa H., Ateya B., (1967), Microchem. J. 12: 440.

18. Khalifa H., El-Sirafy A.A., (1967), Fresenius Z. Anal. Chem. 227: 109.

19. Florely K., (1979), "Analytical Profiles of Drug Substance" Vol. 8, Academic Press, London, P. 300.

20. Miller J.C., Miller J.M., (1993), "Statistics for Analytical Chemistry", Ellis Horwood, Chichester, Ch. L P 96. 